\title{
Images Outside the Mirror? Mozambique and Portugal in World History
}

\author{
Maria Paula Meneses \\ Centro de Estudos Sociais, Universidade de Coimbra, Portugal \\ Menesesp@ces.uc.pt
}

\begin{abstract}
The author, speaking as a Mozambican researcher living and working in Portugal, examines the different types of knowledge about the history of the colonial relationship and the independence movement produced in the two countries. The colonial project entailed the construction of (at least) two divergent narratives on the meanings of the Portuguese presence in Mozambique, narratives that render difficult any possibility of mutual recognition. Colonialism involved much forgetting and silencing; the dominant Eurocentric perspective on colonial history needs to be questioned and problematized. This is not contradictory with a critical questioning of the official post-colonial narrative of the independent Mozambican state, whose nationbuilding function caused it to silence the diversity of memories generated by the interaction between colonizers and colonized and to justify the repression of those who questioned the official version of history. Public narratives, official or otherwise, that construct or reconstruct memories are inevitably in competition with each other and reflect power relations. But the full plurality of memory does not receive public attention; it must be dug out by activist researchers who are able to distinguish subject and object and to produce knowledge in full understanding of the complex relations created by historical legacies.
\end{abstract}

\section{INTRODUCTION: THE COLONIAL LIBRARY}

Não vamos esquecer o tempo que passou, Quem pode esquecer o que passou? ${ }^{1}$

\footnotetext{
1 "We will not forget the time that passed. Who can forget what passed?" Popular revolutionary song of Mozambique.
}

One cannot listen only to the tale of the hunter; the lion has its version too. ${ }^{2}$

This paper aims to discuss the role of memories and history, as a bridge to broaden the debate on the meanings of decolonization and human movement in

\footnotetext{
${ }^{2}$ African proverb.
}

Maria Paula Meneses is a senior researcher at the Centre for Social Studies, University of Coimbra. Previously she was a Professor at Eduardo Mondlane University (Mozambique). Her current research interests include post-colonial debates, legal pluralism, with especial reference to the relationships between the State and 'traditional authorities' in the African context, and the role of official history, memory and 'other histories' within contemporary identity debates, with an emphasis on contemporary Africa. Currently she is coordinating two research projects focusing on the (dis)encounters prompted by the colonial encounter: "ALCORA: New perspectives on the Colonial War" and "The collaborators': Questioning the Future of the Past in Mozambique." Her work has been published in several countries. Recent publications include co-editing, with Boaventura de Sousa Santos, a volume on "Epistemologies of the Global South" (Almedina 2009 2011; Cortez 2010), integrating contributions of scholars from Africa, Asia, Latin America and Europe. The author wishes to thank everyone who has made this publication possible. She is grateful to FCT, whose grant PTDC/AFR/103057/2008 - FCOMP-01-0124-FEDER-008664 funded part of this research. 
spaces defined by the 'memory' of Africa in the specific geopolitical context of the Portuguese colonization in Mozambique.

Regarding the meaning of concepts we often use uncritically, one of the first questions that we have to ask is: What is 'Africa'? In Portugal, as in other former colonial metropolis, the expression is quite often used to refer to the former African colonies, an expression that seeks to include the complexity of the continent. To speak of 'Africa' in an era that is still captive of old colonial epistemological legacies requires that we, above all, open the historic time to challenge representations of space. This situation is neither unique nor original; indeed, many academics have been addressing this matter. What, in my view, is important when we speak of Africa, is seeing to what extent we are not referring to an intellectual construction of western colonialism. In this sense, what do we know, and what do we know about Africa? This question is particularly important in Mozambique, where many people frequently affirm, vis-à-vis the 'official history' or the 'universal history,' that "what we remember is not history. History is what is written in the books. We, Mozambicans, we have traditions, other histories...." 3

To speak about Africa and to forget Africa are two different components of relatively recent colonial processes. The imperial European governments, in search of colonies, created civilizing missions to save the souls of Africans. Entrepreneurs and scientists also participated in drawing the map of Africa as they searched for new investments based on the exploitation of natural and human resources. They drew this 'European' map according to their ideas of Africa, a map constructed through their knowledges and scientific horizons. But according to Portuguese official rhetoric of the time, modern colonialism was not

3 Collective interview, Mapulanguene, Mozambique, 2000. about exploitation but civilization. With the superiority of the race, Catholic values, science and economic know-how, the Portuguese insisted instead that they had moral obligation to redeem the 'backward heathens' of Africa. The Portuguese were going to bring light to Africa, the Dark Continent, by transforming the so-called natives into progressive citizens, ready to take their place in the modern world. According to this reasoning, the Portuguese were not actually stealing land from the people that occupied the territory later known as Mozambique, ${ }^{4}$ or exploiting local labor; instead, they presented themselves as self-appointed trustees for supposedly vulnerable natives, who had not yet reached a stage on the evolutionary scale that would allow them to develop or make responsible decisions on their own (Meneses 2010a). The result of this moral, political, economic and scientific appropriation of the continent by the modern colonial machine was to deny, then and now, recognition of the diverse ways that the concept of 'Africa' is hidden and forgotten.

This 'new' Africa resulted from the colonial European imagination that constructed the African object. "The geographic expansion of Europe and its civilization [...] submitted the world to its memory" (Mudimbe 1984:xxi), an imaginary persists in many publications, scientific and literary. With appropriate guidance and paternalistic love, the Portuguese administration assumed that it could make the Africans into progressive men and women, although it would take long time, even centuries, to perform such a radical transformation. This conception about the 'natives' remained relatively unchanged throughout much of the $20^{\text {th }}$ century; this was the White Man's burden.

Questions of the memory or memories of colonization, and the probing of the

${ }^{4}$ As they did in other parts of the continent, such as Angola, Guinea Bissau, etc. 
meanings and impacts of the modern colonial abyssal fracture, continue to profoundly affect the contemporary academic and political field (Cooper \& Stoler 1997; Blanchard, Blancel \& Lemaire 2005; Bertrand 2006). For the most part, this area of research continues to be actively suppressed from the European conscience of former colonial powers despite the fact that the theme of colonization is an object of specialized studies in specific thematic areas (Santos 2001; Smouts 2007). The accumulated amnesias of this continent and the enforced silence regarding what the Africans' think about Europeans were intentional acts of forgetting signifying a denial of any possibility of mutual recognition.

Forgetting and silencing are central moments of colonization. To question coloniality and its impact on knowledges, and the persistence of misunderstandings and misreadings, demands the historicization of these spaces, these times, and the analysis of power relationships entailed in the multiplicity of contacts that occurred between Europe, Africa and the other regions of the world. ${ }^{5}$ In short, it requires another history, rewritten by people made invisible by colonial power, through the artifice of exceptionalism, by turning European thought into the supreme example of world development, the very embodiment of 'world history,' that is, of a linear progression from ignorance (savagery) to knowledge (civilization). In Mudimbe's words, "offering and imposing the desirability of its own memory, colonization promises a vision of progressive enrichment to the colonized" (1994:129). When the European colonizers contemplated Africa through the prism of their desire to conquer and dominate, they saw nothing but desolate lands,

\footnotetext{
${ }^{5}$ If one privileges the study of the relationship between Africa and Europe, one risks to miss the broader picture of contacts established with other regions of the world - notably Asiaand its impact in the production of contemporary Africa.
}

diseases and 'natives' to be tamed. ${ }^{6}$ This memory of Africa erased, and still erases, all traces of African cultural imprints on the land. It became part of what Hegel termed 'unconscious nature. ${ }^{7}$ The Eurocentric memory became the beginning of history for all the colonized-a process that means the loss of their own history. When colonized peoples have their memories, land, and power torn away from them, the result is the destruction of the base from which people launch themselves into the world. World (Eurocentric) history ${ }^{8}$ became the imperial road to power and domination.

An alternative reconstruction of world history that includes voices that question and problematize the continuing dominant, Eurocentric perspective would fulfill a responsible pedagogical public function. An 'other' possible historiography would need to address controversial issues that challenge the position and legitimacy of dominant representations. Rather than generalizations and simplifications that try to 'confine' Africa into a scheme developed to explain in linear fashion the progress of Occidental civilization, we face a double challenge: to explain the persistence of the colonial relation in the construction of world history while at the same time proposing alternatives as to how this story is interpreted. Constructing contextual

\footnotetext{
${ }^{6}$ It is interesting to note that European medieval world, as Du Bois puts it, "knew the black man chiefly as a legend or occasional curiosity, but still as a fellow man - an Othello or a Prester John or an Antar" (1915: 6). The modern, capitalist colonial world, knows Africa only as a place of inferiority, symbolized in Hegel, who, in his lectures on the philosophy of history, describes the African continent as having no history for it was still enveloped in the dark mantle of the night.

${ }^{7}$ When any part of the African continent exhibits marks that might compare favorably with the Western world, it was 'removed' from African history and annexed to it, such being, for example, the case of Egyptian civilization, portrayed as being part of 'Mediterranean world,' the European Africa.

${ }^{8}$ Planted on places and bodies, by imposing the right to name, to inscribe other knowledges and epistemic references.
} 
histories, articulated within a web, would allow us to attain a cosmopolitan perspective of the world.

\section{AfRicA, History, Histories AND MEMORIES}

The history of Africa has been marked by the devaluing of memories-in the plural-where the past acquires similar forms to the future, full of problems and populated with dense silences. The crises of time-when it seems that one does not have time for memories-do not occur only because of the increasingly dominant presence of neoliberal globalization; they also derive from a present replete with amnesias. Further, they are connected to the crises of singular explanations of the world, the crisis of the meta-narrative in history, specifically regimes of totalitarian power that sought to control the regimes of memory in a centralized manner.

Strategies of colonial interpretation of post-colonial situations operate by essentially trying to conserve an explanation that justifies and does not challenge the underlying colonial presence in the knowledge produced. Even today, years after achievements of political independence, the countries of the African continent are often identified as Lusophone, Francophone or Anglophone. For the case I am analyzing, the so-called Portuguese Africa was transformed into 'Lusophone Africa'; 'Our [Portuguese] Africa'; the 'PALOPs,' or Portuguese-speaking African Countries. The exceptionality of these countries draws from their 'belonging' to an old colonial project, relentlessly present in their foundation, erasing other histories or exceeding them-the ubiquitous link to Portugal. ${ }^{9}$

\footnotetext{
${ }^{9}$ What made Mozambique unique in 'Portuguese colonial Africa,' along with Angola, was the settlement of white colonists who were expected to form the economic and political leading backbone of the colony.
}

But colonialism is a confrontation of different societies, each with its own memory. The Portuguese colonial ideology, seemingly monolithic and supported by expansionist practices, regarded the mass of African social formations-each having different and often particular memories, competing with each other-as a single entity, binding them together. This pitiful picture persists and is reproduced in many ways (Meneses 2010a). What has actually changed, if anything?

One can no longer speak of a single macro-narrative, of only one interpretation of history. In other words, the problem operates inside of a 'single analytical field' and is seen only at the discursive level. The issues, the scale, and the location of these places remain unresolved. And this brings back the question of decolonization. ${ }^{10}$ This thorny concept claims for a broader reconceptualization of the ruptures associated with the end of political colonization. Did the representations of the colonial world change the same way both in the former colonies and in the metropoles?

Europe planted its memory in the very core of Africa. This phenomenon is not particularly European; rather, is in the nature of all colonial conquests and systems of foreign occupation. Attempting to (re)create the land and its people, to reconfigure the territory, the Portuguese, like other colonizers, asserted their right to name the land and its subjects, demanding that the subjects accept the names, references, culture and history of the conqueror (Thiong'o 2009:9). Thus, one must question why there is such a resistance to opening up the canon of macro-history, the macronarrative of world history. As several people interviewed in Mozambique would state, it does not make sense to exist without remembering the past and without

10 To explore the concept of decolonization from a postcolonial perspective, in African contexts, see, for example, Bragança 1986 and Sheppard 2006. 
imagining the future; questioning from where we came and to where we will go. Walter Benjamin writes that memory "is not an instrument for exploring the past, but rather a medium" to do so (1999:576). Memory is essential to constructing an identity, that of an individual as much as that of a collective. To starve or destroy memories results in liquidating the past, the history that binds people together, that makes them what they are.

To impose a single history is to impose the weight of experiences it carries and its conceptions of self and otherness-indeed, the weight of its memory, which includes several factors, such as religion and education. ${ }^{11}$ The signs of this project can be traced everywhere, especially in claiming the memory or memories of collective pasts which, being unique, are distinct from a single and vague general past. The quality of being unique is not allowing them/ others to identify with us. While the persistent routes of nationalisms are not always healthy in their principles and intentions, they at least signify that the situation of amnesia generates much conflict when imposed on a global scale, as Aquino de Bragança and Jacques Depelchin once anticipated (1986) when analyzing the construction of Mozambican history after the country's independence.

This, in part, signifies that we remain involved in the search for other parts of history/histories, of other people/peoples, facts, and other institutions that are silenced and almost erased. This is a sign of the continuation of the struggle for liberation, against amnesia, against attempts at silencing. Again, one needs to cautiously approach the relationship between forget-

\footnotetext{
${ }^{11}$ Cheikh Hamidou Kane, in his novel $A m$ biguous Adventure, insightfully remarks the power of colonial schools in the subjugation of the colonized. He credits the schools as having even more power than the cannons for they made conquest permanent, as "the cannon compels the body and the school bewitches the soul" (1963:49).
}

ting, these intentional memory lapses and the work of the ethnographic collection undertaken by Africanist researchers, by ethnographers that fill the infinite shelves of the colonial library. The practices of producing knowledge about the African continent were, in actuality, guided by objectives designed to operate and legitimize one determined project: the colonial mission (Meneses 2008). Possibly one central problem of this work has not been failing to develop some conceptual aspects such as rituals, magic, fetishism, paternalism, and the traditional local authorities, but the reaffirmation of tradition, of a primal space and the continent's inescapable mark of delay. This is not to argue that the colonial archives cannot be used, quite the contrary. They should be used with necessary precautions that analytically take their potential biases into consideration. Accentuating tradition impedes us from seeing and questioning the problems of a Mozambican working class that has been present for more than a century, ${ }^{12}$ and the dilemmas it confronts with the current economic crisis. Emphasizing the study of rural tradition prevents us from analyzing and conceptualizing the urban complexity of many African countries. Or rather, we risk making them immune to the modernization that also happens within these spaces and within the present. We risk making them immune to discussing the implication of authoritarian regimes in situations of multiparty, of the implication of cultural 'uprootings,' etc. The present, which constructs narratives about the past, is also worth celebrating.

\footnotetext{
12 In this sense, the role of migrants from Mozambique in the mines of South Africa since the nineteen century must also be taken into consideration to broaden studies on how the revolutionary consciousness was developed in this region of the continent.
} 


\section{MOZAMBIQUE: THE STRUGGLE CONTINUES}

The nationalist struggle in Mozambique, as in other contexts, brought about the need to reconstruct the history, confronting the dominant colonial narrative. In short, independence called for a reanalysis of the histories, now in the plural.

The end of authoritarian narratives does not necessarily mean that delayed realities remain incompatible with time forever, or even worse, suspended outside of it. It is not a synonym for the end of history because whatever existing society is, it is part of time. On June 25, 1975, Mozambique woke up independent, with a sense of urgency regarding the reconstruction of its history. As we sang at the time, "we will not forget the time that passed." A current challenge is the recuperation and the production of memories. Identities were created and political alliances forged, to give a meaning to life and to help explain the importance of fighting Portugal's colonial-fascist presence in Mozambique.

Colonial relations came in many forms, such as conquest, rebellions, religious missions, scientific exploration, education, medical services, commerce and economic exploitation, voyages, art, etc. In addition to the absolute denial of the colonized, colonial relations, often marked by domination and violence, are also characterized by multifaceted processes of appropriation. There were numerous forms of appropriation, such as religious, economic, demographic, political, linguistic, artistic, intellectual, etc. With different intensities in space and in time, these appropriations and (re)creations generated contradictions and conflicts throughout this process. Although asymmetrical, any process of appropriation encompassed a double relationship. This aspect is extraordinarily important because it reveals how colonization describes situa- tions of political control over a given territory by a foreign force with objectives to incorporate and exploit it. Colonization hence goes much further than the restricted meanings we sometimes use to discuss the subject. Secondly, questioning these colonial relations in our time opens the subject to perceiving the ruptures and continuities of the colonial relation. If decolonization is a political relationship, as a political process it impacts upon the multiple parts involved in the colonial relation, now confronted with a dramatic change of power relations. Analyzing the Mozambican reality, Aquino de Bragança would dare to affirm that the power transfer occurred without any impositions from Portugal. Thus, the Mozambican case could mean the possibility of a political transition without the weight of the neocolonial relationships usually attached to it (Bragança 1986)

In this context, to speak of colonial legacies is to recognize, firstly, that colonial relationships contributed to formatting any history, suggesting that this relationship persists in how the world is perceived today-even though this legacy is not always recognized in a legal or cognitive sense by its potential heirs. This means that what remains in the past is more than a memory. To question the place of memories implies questioning the place where we inquire into the memories about ourselves. Portugal's colonization of the African continent can be analyzed in terms of how the situation impacted the regions ${ }^{13}$ where the process took place and by examining how the very meaning of being European was objectively ${ }^{14}$ and subjectively constructed by the colonial experience. Within colonial juridical thought, the concept of Portuguese citizenship does not refer to an abstract category-quite the contrary.

\footnotetext{
13 "Amor e vinho (idílio pagão)" article published in the newspaper, O Africano, 11 June 1913.
} 
Portuguese citizenship identified a specific, socially concrete, and moral standard: it applied only to white men and women born in Portugal, well-educated and wealthy, the "genteel soul of colonization." In such a manner, to be European became a category that defined a status and determined these relationships. To be European came to mean being part of a certain geopolitical strategy of power, a space dominated by a modern rationality which wore the color white.

Part of this reflection reflects my place of questioning. As a Mozambican researcher working in Portugal, my perspective on contemporary Portuguese society begins its interrogation from spaces that are most familiar and from my places of belonging, Mozambique. These reflections also reflect my path, my commitment to research in the field of social sciences. The political turbulence of the 1970s and the 1980s in Mozambique was informed by scholarship, including empirical analysis, debates about agency and intervention, philosophy and history. It also included scholarly and activist publications (Borges Coelho, 2007). A peculiar aspect of this knowledge production was the fact that many of the persons involved in its production were not professionally trained academics. Still, it became possible to bring other voices, other problematics to the process of decolonizing Mozambique and freeing the country from the weight of colo-

\footnotetext{
${ }^{14}$ An attentive reading of the legal codes reveals an abyssal frontier between nationality and citizenship. The 'blacks' were nationals of Mozambique and were deprived of rights to citizenship and submitted to a specific and extremely repressive disciplinary regime, the "Regime of Indigenato," abolished only in 1961. Under this regime, legal citizens (legal being the Portuguese) - acknowledged themselves as invested with the right to govern the subjects that were declared to be further behind on the road to progress and civilization. The legitimacy of their political power rested on the colonial mission to assimilate the 'less developed' into a model of life that was defined superior by the 'citizens' (Meneses 2007a).
}

nial history.

Portugal and Mozambique shared places with each other but they hardly share memories. It might be more adequate to say that they have shared silences and a lack of contact. In the more than three decades since its independence, Mozambique has come to grasp the difficulties that recognizing this aspect of sharing entails. This awareness raises very complex questions inherent to the memory of the relationship between the colonized and the colonizer. Beyond historiography of a common period, it would be more precise to speak of two historical macro-narratives developed upon a common denominator within the same territory and the same conflict: a macro-narrative about a colonial war in the final era of the Portuguese imperial colonization, ${ }^{15}$ and another one, seen from the Mozambican side, about the process that led to the national independence of Mozambique.

These two histories have distinct paths that were influenced by the social memory of what 'happened' and by how it was politically generated. Working now as a researcher in Portugal, it has been a curious transition from forgetting the 'omitted' to a growing presence of this relationship and sharing. Yet even here, no one speaks of the reasons behind this war. Very few seek to understand why the war has two names that reflect different paths and different interpretations. After all, when did the colonial war begin? What was the colonial war? Why is it said to have started only in 1960 when all who ponder over this theme have 'other' colonial wars in mind? The 'other' colonial wars date back to the very end of the 19th century and the early 20th century and were at the time called "campaigns of occupation."16

\footnotetext{
15 The Portuguese colonial war, fought simultaneously in Angola, Guinea Bissau and Mozambique.

${ }^{16}$ On this subject see ; Albuquerque 1935; Caetano 1947; Ennes 1971, 2002.
} 
In the south of Mozambique, where the military campaign was against the state of Gaza, the struggle ended at the very end of the $19^{\text {th }}$ century (Albuquerque 1935; Ennes 2002). When the Portuguese finally imprisoned the head of Gaza state, Ngungunyane, they condemned him-together with his closest political advisors-a life of exile in the Azores, that is, in Portugal. Ngungunyane died there, in semi-captivity, without ever being submitted to trial. A thread of violence connects these violent campaigns with the final stage of the colonial presence of Portugal in Mozambique, in the 1960s. There are shared moments united by distinct memories; they rest upon the thin lines that link the military vehicles, the 'Chaimites, ${ }^{17}$ which occupied parts of Lisbon, on the dawn of the coup d'etat of April $25^{\text {th }}$-and which came to symbolize the liberation from the colonial dictatorship in Portugal- to the war against the state of Gaza.

The fate of Ngungunyane-simultaneously acts of triumph and humiliationembodies the colonial relationship between Portugal and Mozambique (Meneses 2010b). This colonial act was both a practice of power, intended to pacify a populace, and a performance of power intended to produce docile minds. The fate of Gaza state also symbolized the dismemberment of the colonial subjects from the individual and collective body. The colonial fracture, represented in the exile of Ngungunyane, was characterized by dismemberment and omission of former political structures, by the attempt to bury all the memories these subjects carried.

On the other side, in Mozambique, the quest for memory has followed a different

\footnotetext{
${ }^{17}$ Chaimites were armored military vehicles, produced in Portugal to fight the guerrilla nationalist movements. They were named after 'Chaimite,' the sacred capital of Gaza state (now in Mozambique), defeated by the Portuguese in 1895. Chaimite became the symbol of the submission of the 'colonial other.'
}

path. Or rather, from a strong remembrance of Portugal as a symbol of the colonial relation aimed at creating a sense of national unity, $^{18}$ people have been sliding toward forgetting.

Throughout most of its short history, the Mozambican state has pursued a nation-building policy that includes the political adoption of an official history grounded in a set of public (and intensely publicized) memories about its colonial past, both recent and distant (Meneses 2007a). The Mozambican state has thereby sought to eliminate, silence or make invisible the diversity of memories generated by the complex social interactions between the colonizers and colonized over the long period of Portuguese colonialism. Soon after independence, FRELIMO,${ }^{19}$ the leading political force in the country, carried out a complex political strategy that sought to deal with the ambivalent and hybrid identities that constitute the intricate colonial legacy. To put an end to all forms of possible continuities with the colonial past, the target of this policy became those caught in 'transition,' i.e., the 'collaborators' - a rather diverse group that is rarely spoken of, if not virtually omitted (the estimated size of the group is 100,000 people). ${ }^{20}$ The 'collaborators' were accused of having collaborated with the colonial system, up to the indepen-

${ }^{18}$ Contained in the attribution, for years, of the political conflicts and errors of Portuguese colonialism.

19 FRELIMO is the nationalist movement that led the fight for the independence of Mozambique from Portuguese colonization. Afterwards, it turned into a political party and has been in power since independence, both during the single-party and multi-party periods.

20 A process of 'Portuguese indoctrination' started in Mozambique during the 1960s (Borges Coelho 2003; Souto, 2007) when colonial enlargement policy sought to extend Portuguese identity to the overseas populations overseas in Africa. When the pressure of the liberation movement increased, especially in the military, such actions were taken to convey the idea that Mozambique was an integral part of the Portuguese nation and that all the former colonial subjects were Portuguese. 
dence of Mozambique; FRELIMO's politics of memory was founded upon the idea of "not forgetting the time that passed." This strategy aimed "to transform the collaborators based on presumption of guilt, repentance, punishment and re-education" (Coelho 2003:191). In the aftermath of this political process, in the early 1980s, most of the 'collaborators' were recognized as politically re-educated and accepted as full citizens. Their subsequent rehabilitation was obtained at the cost of erasing their past from the public sphere and treating it as a past that was to be kept a private, silenced memory.

The guerrilla nationalist was projected as the icon of the truly Mozambican citizen, the model of the 'new man.' The myth of the guerrilla nationalist was created as an attempt to generate new political identities during the first years of independence. Mozambique was cast as being made up of two main groups: those who had fought for independence and the others who made up the mass majority of Mozambican society. These moments of hierarchization after independence derived from the necessity to "limit the electoral capacity of the citizens who were committed to fascist colonialism." 21 The category of second-class citizens included many of those whom FRELIMO identified as having been allies or supporters of the Portuguese colonial presence (Meneses 2007b). Shortly after independence, FRELIMO sought to overcome the separation thus created between those deemed to be 'collaborators' and the 'Mozambican population.' In 1977-78, the first signs of a political strategy seeking to deal with the memory of these colonial connections emerged. Samora Machel, then the president of Mozambique, had not

${ }^{21}$ In this manner, the introduction to the first electoral law in 1977 distinguished between those that were involved "in the colonial structures of the oppressor" and the "Mozambican people," the former being prohibited from political participation. opted to form a Truth and Reconciliation Commission. He addressed this issue in several speeches, culminating in an important public meeting in 1982. The multiple meetings and the integration processes for the 'collaborators' can be seen as an unofficial Truth and Reconciliation Commission, which sought to elucidate, clarify, and offer knowledge about the complexity of these Mozambicans' history.

The 'collaborators' were a significant and extremely heterogeneous group, lumping together all who did not 'fit' into the epic story that fabricated the 'new man': the project of the new Mozambican citizen. ${ }^{22}$ They were those who had given in to temptation, having committed themselves to the colonial system. Among them were former members of the Portuguese political colonial police, the PIDE-DGS; members of $\mathrm{ANP}^{23}$ soldiers in the Portuguese army; the godmothers of war, traditional authorities, politicians, members of the lower echelons of the administrative apparatus, or those who "were not with us [with FRELIMO]." Seen as the traces of the colonial presence, re-routing and re-educating memory through forgetting was an important task that Mozambique sought to fulfill.

However, if the question of political content and ideology confronted within the liberation movement in Mozambique is present in political analyses of these struggles, it is directed towards comprehending the distinct geopolitical contexts of these countries. In Portugal, I have learned about the peculiarities of this situation. My work is not on Portugal and it is my objective to debate the course of historiography or the collective Portuguese memory from this period. What is surprising when analyzing the situation from Mozambique, nevertheless, is the rediscovery of African issues by

${ }^{22}$ See, on this subject, Meneses 2007b.

23 PIDE-DGS: the repressive police during the dictatorship. Acção Nacional Popular: the single political party that ruled Portugal throughout the period of the dictatorship. 
academia in Portugal, which still largely declines to recognize other memories of this war, the reasons behind it, and the political projects involved in it.

In Mozambique, the heart of national history is located in the memory of the struggle for national liberation. The heroes are those produced by this struggle, with which Mozambique began. The construction of this history rests upon a politicization that was exacerbated by the process of constructing the national political memory. The construction of membership was founded upon a political analysis that accentuated the dichotomization of spaces between "liberated areas" where "the new man was being produced" and the colonial territory perceived as a negative space of past legacies. Even if the territory was inhabited by a great majority of Mozambicans up to that point in time, it was, as I previously mentioned, necessary to extirpate it. These too are colonial legacies (Mbembe 2002).

\section{A Map of Conflicts: The NATIONAL HisTORY}

The tension between the national project, or the modern territorial base that was mapped, legislated and historicized by the hand of colonialism, and the successive (re)constructions of various identities that were present in the geocultural territory identifiable as the Mozambique of our times, has translated into a co-habitation that was never peaceful (even when interpreted as such by those in power) and involved very little dialogue. This reality manifests itself in the successive reconfigurations of conflicting identities (ideological, ethnic, racial, and religious) that have generated other presuppositions and concepts that have helped to define other geo-cultural places that came to be named as Mozambique, but in which other peoples, other cultural, linguistic, and reli- gious archives were also present. The long duration of the history requires some analytical breath when focusing on the specificity that Mozambique is today.

In modern times, the most visible expression of opposite narratives to those of the colonizers is the grand narrative generated by the anti-colonial struggle, centered upon denouncing colonialism and its vices (discrimination, subalternization, concealing of knowledges, etc.) and the elaboration of a national project for the future. From this narrative, promising more of a new future than of a possible review of the past-and nationalist although quite Eurocentric in its core, but organically local-emerged the idea of a Mozambique for Mozambicans, and what came to be designated as Mozambicanness. The country's call for equality caused the dramatic erasure of the differences that made its social fabric, generating profound contradictions, synonymous with the continuities of imperial mechanisms that remain active (Meneses \& Ribeiro 2008). For example, how does one situate the idea of the nation driven by the anti-colonial struggle with other grand narratives, such as ethnicity, race, religions, and gender? Where is it situated in relation to the 'new' discursive hegemony that is linked to the national project? Before independence, but mainly after independence, the political project of Mozambique and the political project of FRELIMO seemed to coincide. The 'literature of combat $^{24}$ was one of armored weapons; it promoted the nation's struggle for 'recovery' and was imbued with the mission of inventing a single past that could create 'Mozambicans,' who, without fracture and without difference, were united against a common enemy, colonization. In short, proposals that rejected, amended and, finally, posed a challenge to the hegemony of the national

\footnotetext{
${ }^{24}$ Literature produced during the nationalist army struggle.
} 
project created in the midst of an exogenous proposal, ${ }^{25}$ questioning its value as representing the Mozambican nation, while simultaneously debating its discontinuity with the Mozambican state. ${ }^{26}$ Such narratives question the single sense of historiography, with its heroes and national myths, which are more elaborated than organic. ${ }^{27}$ In fact, in the literature of combat, found upon the figure of revolutionary 'combatant,' it became possible to integrate only very partially and in a very subaltern way the urban intellectual. The project of constructing the 'new man' did not captivate the memories of the past or the diversity of the present. Nevertheless, diversity insisted upon its presence, finding other forms of protests and affirmation: art, music, literature, etc.

The construction of proposed political alternatives to the colonial situation both denounced the empire and sought, simultaneously, to make a "new revolutionary subject" visible-the revolutionary Mozambican who identified with the people and whose purity was filtered by the modern nationalism distinguished by FRELIMO. This political context explains the trial of various nationalist ex-political prisoners (including such renowned poets as José Caveirinha and Rui Nogar, and the painter Malangatana Valente ${ }^{28}$ ), in 1977, for contradicting the monopolizing vision of FRELIMO over the meaning of nationalism. ${ }^{29}$

If we allow decolonization to question

\footnotetext{
${ }^{25}$ As a geopolitical project, Mozambique is the result of the division of Africa carried out in the Berlin Conference in the late 19th century.

26 The 2004 national constitution, for example, recognizes the multicultural character of the country (art. 4).

${ }_{28}$ For example, see Ncomo 2003.

28 See Laban, 1998.

29 As Craveirinha later explained, these former political prisoners, who were accused of treason and then submitted to re-education processes, underwent a difficult period of political marginalization after independence (Laban
} 1998). the impact of violent and exploitative relationships, we will find that our legacies and memories are far short of decolonization. Recognizing this problem brings us to the urgency of a critical engagement with current political consequences, both intellectual and social, of centuries of Western 'expansion' in the colonized world to dispute the naturalization and depoliticization of the world. In one sense, postcolonialism is greater than the meeting of various perspectives and concepts of power, for it is a language which seeks to reflect upon processes of 'decolonization' as they take place in the spaces of the metropole and those in colonized spaces.

In the latter, historical reinterpretations were necessary to rescue Mozambique from the silence of interpretations imposed by colonial history. From the outset, this reinterpretation was imbued with revolutionary purity and was indisputable because it was constructed from the testimonies of FRELIMO's leaders, the living heroes that fought for national liberation. This process did not need a mediating historiography; rather, what was needed was to avoid inquiring about sources and about alternative interpretations that were likely to cause disputes.

Thus, the time and space of liberation came to be 'made history,' which was more likely to be disseminated than questioned or interpreted. For academic consolation, the colonial situation emerged into an excellent space for research and inquiry into a new history from silenced memories. For Aquino de Bragança and Jacques Depelchin (1986), history, as an academic discipline, had to play a key role in constructing national political memory. However, the opening to democracy and to a multiparty system that Mozambique witnessed in the 90s allowed the surfacing of other moments of questioning and other hidden spaces of violence. (Re)constructing 'Mozambican-ness' was necessary, yet this new political project now had to integrate 
these other, less politically instrumental memories. These memories, however, did not meet great challenges through new interpretations and new versions. A political reading of the complex situation in Mozambique reveals a peculiar characteristic of its political process: the multipartidarism of a single party (Meneses \& Santos 2008). The armed struggle for national liberation could not be claimed as the only foundation of Mozambican unity since there were other conflicts and other political processes. As the elders frequently say, "because our dead still speak very loud," in Mozambique it was not worth speaking of the past because that brings back the shadows of memories we do not want to remember. Contrary to Portugal, the emphasis in Mozambique was on the need to struggle for liberation, the roots of the struggle and not the struggle itself. Nevertheless, the evolution of the nationalist movement can only be understood within its broader context, taking into account, not just influential internal factors, but all the factors resulting from the confrontation with colonial power. In this sense, the conjoining of memories was due to a convocation of all memories-nationalist and colonial—to comprehend this moment of rupture. Mozambican history needs colonial sources, and Portuguese history also needs to analyze the sources of the liberation movements involved in the war. These are two sides of many remaining histories to be studied.

Let us return to the factor of time in our analysis. Always speeding ahead, time constructs the past. An immaterial shadow of what happened, the past is a narrative created in the present. Its discourse approaches the past, but it is not the past. Such constructions occur in many forms: music, art pieces, oral history, etc.; all are forms of conjugating the past into the present. All are forms of organizing time beyond formally written narratives.

Public narratives, explanations, constructions of official memories are always complex due to the number of players and the number of intentions that produce them. Yet again, these plural memories reflect power relations by being one of many versions produced by players that predominate over others. There are many actors that participate in the production of memories: individual actors, collective actors, institutional, private, etc. A historical memory that is produced by historians is only one of many strands.

There are in fact others that we cannot forget if we seek to make the analysis of our societies more complex. It is not possible to construct official narratives by ignoring the collective memories of groups that are silenced for some reason. Political memory or official history already seeks to construct a unifying narrative within the national space to create social cohesion and legitimize political options. The History of Mozambique is the history found and taught through textbooks, but it collides with other, parallel memories.

Therefore, one needs to address these various 'locations' of memories, the epistemic 'discovery' of an otherness, the presence of multiple memories. This is the first moment that announces changes in relation to the official memory, with history as a macro-narrative of our societies. The second is recognizing the process of constructing history from this otherness and from its recuperation.

\section{CONCLUSION: WEAVING NARRATIVES, CONSTRUCTING HISTORY}

The debate about investigation and presentation of the African continent exposes a problematic reality, a "theoretical extroversion" characterized by the importation of uncritical paradigms, problems and perspectives, by politicians and African intellectuals alike (Hountondji 2002, 2009). 
Today, contemporary Africa needs to confront two major inquiries: analysis of the implications of the colonial legacy for itself, and the quest to recover that which came before colonization and has remained present in its social structures, its political structures and its identities. The objective is not to create a conceptual space for the other, but recognizing that otherness is a constant in processes of social development.

During the colonial period, the denial of this condition resulted in keeping otherness outside the time of civilization and its transformation into the time of culture, the time outside the space of Western (read: colonial) modernity.

Today the problem is more complex. On one hand, we often continue to make our interpretations from a center that still has not been 'decolonized.' It is hence through the eyes of Imperial Europe that these African spaces are still perceived through epistemically colonial lenses. On the other hand, while we want to (re)construct other histories and (re)introduce ourselves to the debate of other memories, the situation we observe reflects the difficulty of constructing another analytical grid which would escape from dominant interpretations and allow us to introduce the memories of other actors.

Imperial projects have hardly been reformulated, maintaining themselves in the essentially hegemonic conception of the Global North over the Global South despite the independence of African countries and the end of the so-called Cold War. ${ }^{30}$ The questions raised by debt, migration, weak or "problem" states, world poverty, and institutional and epistemic racism are among the moments that bring to our atten-

\footnotetext{
${ }^{30}$ Indeed, the cold war, as a concept, applies to very restricted areas of the globe; specifically, in the case of the African continent, wars and severe conflict situations were experienced throughout the entire $20^{\text {th }}$ century, thus questioning the validity of the use of 'cold war.'
}

tion the persistence of colonization. Many academic relations in the fields of anthropology and history express and treat this colonial expression as the persistent memory of colonization and as a power relation. In this sense, constructing contemporary histories in our times is perhaps one of the principal elements necessary for the (re)emergence of another subject as well as an active political actor. We become aware of ourselves and others, recognizing that the presence of an 'other' implies that we must know the past and the paths of other(s).

To think of memories in the plural, placing them as diverse narratives of histories about locations, involves an obligation to think of identity processes, or the social and political metamorphoses known to societies. If we agree that recognizing signifies remembering the other, the relationships between ' $\mathrm{I}$ ' and the 'other' become spaces of struggle for recognition, spaces of democratizing memory and of the knowledges that they convey.

Even the collective memory that we call 'our memory' and which seems to overlap with others, is not anything real or concrete. On the contrary, 'our memory' is also a narration, a story of 'arrival' and the resulting construction of memories (history, community, etc.) articulated within present power relations. The integration of memories into a whole occurs though political filter managed by political memory; or rather, by the 'officially' established bodies of power.

Historians tend to use the notion of memory to incorporate unauthorized or unofficial versions of the past while groups whose identities rest upon a specific history challenge legitimate versions of the past and the monopoly of experts, as a "duty to memory" (Bensoussan 1998; Ferenczi \& Boltanski 200; Ruscio 2005).

As a result, new silencing occurs, and, as previously mentioned, since there are many variables at work in constructing 
these memories, there will always be segments of memory that feel excluded or insufficiently integrated. What to remember, and for whom? Who are we and where are we going?

The way to address the questions of memory is therefore to recognize two essential questions. On the one hand, collective memories have various producers originating from a plural origin, whether it be the point of view of the distinct locations of distinct narrators or perspective of that which is being narrated and the forms the material assumes. On the other hand, if we are to accept the plural origin of collective memory, it is fundamental to manage these diverse producers in an inclusive and democratic manner (Borges Coelho 2007). We often speak of democratizing our societies, yet the histories, memories, knowledges and experiences of these groups escape from the space of this democratization. In this sense, and borrowing from Boaventura de Sousa Santos (2007), the 'silences' that other memories have been subjected to and their absence from imperial academic circuits strongly indicates the presence of alternative discourses that question insistently the centrality of a single, universal history.

Questioning the colonial raises infinite questions in both imperial metropolitan and colonized spaces. The struggle for Mozambique's independence was linked not only to other political processes via aid from the African continent, but also to other outside processes including the struggle against fascism in Portugal. This involved rejecting racial discrimination and the boundaries of difference in a call to join forces to resist colonial and fascist oppression, transforming them into a unified cause against a common oppressor.

To reclaim the past, as Frantz Fanon insisted, "triggers a chance of fundamental importance" (Fanon 1963:210) for the subaltern other. Instead of shame, the past should be branded with "dignity, glory and solemnity" (Ibid.). From this perspective, the silences of the Otherness are not a synonym for the victimization of alterity, but of an increasingly active, and even radical presence of these 'other' historical actors-a condition for transforming the memories and narratives they produce.

This kind of knowledge, or better yet, inter-knowledge, rests upon recognizing the mutuality of differences and similarities, which allows relationships between societies to be reconstructed. The legacies distilled in the memories would not simply be transmitted: they would be repudiated, selectively accepted, falsified and modified through numerous demands and negotiations. They would involve sentiments, nostalgia and envy, remembering and forgetting, fighting for recognition and suspicions of illegitimacy. Like the colonial question, historical legacies create relations (many times quite conflictive) between the potential heirs, simultaneously dividing and connecting the parts together.

Historical scholarship entails distancing the self from the objects of knowledge, which in the case of the activist involvement with a 'new subject' - the history of Mozambique-is the unfair world present 'out there,' which the researcher only tackles minimally. On the other side, and as Radha d'Souza reminds us, "activism involves transcending the subject-object divide, crossing the boundaries between the self as the knower and the knowledge of the world, about a state of being when the knower identifies with the knowledge so completely, where the distinction between the knower and the knowledge is so blurred that the knower is able to make a qualitative leap into the unknown" (2009:35). The production of this 'new' historical knowledge requires the acknowledgment of and distinguishing between the subject and the object. Speaking about others will therefore always have to be sustained by knowledge produced with others in a complex and symbiotic relationship. 


\section{REFERENCES}

Albuquerque, Joaquim Mouzinho de (1935). Livro das Campanhas. Lisboa: Agência Geral das Colónias.

Benjamin, Walter (1999). Selected Writings. Vol. 2 (1929-1934). Cambridge, MA: Belnap Press.

Bensoussan, Georges (1998). Auschwitz en héritage? D'un bon usage de la mémoire, Paris: Mille et une nuits.

Bertrand, Romain (2006). Mémoires d'Empire. La Controverse Autour du 'fait colonial.' Paris: Éd. du Croquant / Savoir-Agir.

Blanchard, Pascal; Blancel, Nicolas; Lemaire, Sandrine (ed.) (2005). La Fracture Coloniale. La Société Française au Prisme de l'héritage Colonial. Paris: La Découverte.

Bragança, Aquino (1986). "Independência sem Descolonização: a transferência de poder em Moçambique, 1974-1975" Estudos Moçambicanos, 5/6: 7-28.

Bragança, Aquino; Depelchin, Jacques (1986). "Da idealização da Frelimo à compreensão da história de Moçambique," Estudos Moçambicanos, 5/6: 29-52.

Borges Coelho, João Paulo (2003). “Da Violência Colonial Ordenada à Ordem Pós-colonial Violenta: sobre um Legado das Guerras Coloniais nas Ex-Colónias Portuguesas," Lustopie 2003: 175-193.

Borges Coelho, João Paulo (2007). Memória dos Dias Moçambicanos de Ruth First. Paper presented at the Colóquio Moçambique no Contexto da África Austral e os Desafios do Presente: Repensando as Ciências Sociais. Maputo (mimeo).

Caetano, Marcello (1947). As campanhas de Moçambique em 1895 segundo os contemporâneos. Prefácio e notas do Prof. Dr. Marcello Caetano. Lisboa: Agência Geral das Colónias.

Cooper, Frederick; Stoler, Ann (ed.) (1997). Tensions of Empire: Colonial Cultures in a Bourgeois World. Berkeley: University of California Press.

D'Souza, Radha (2009). "The Prison Houses of Knowledge: activist scholarship and revolution in the era of 'Globalization'," Mcgill Journal of Education, 44 (1): 19-38.

Du Bois, William Edward Burghardt (1915). The Negro. New York: Henry Holt \& Co.

Ennes, António (1971 [1893]). Moçambique: Relatório apresentado ao governo. Lisboa: Agência Geral do Ultramar.

Ennes, António (2002). A Guerra de África. Lisboa: Prefácio.
Fanon, Frantz (1963). The Wretched of the Earth. New York, Grove Press.

Ferenczi, Thomas; Boltanski, Christian (eds.) (2002). Devoir de Mémoire, Droit à l'oubli? Paris: Complexe.

Hountondji, Paulin J. (2002). The Struggle for Meaning: reflections on philosophy, culture, and democracy in Africa. Athens: Ohio University Center for International Studies.

Hountondji, Paulin J. (2009). “Conhecimento de Africa, Conhecimento de Africanos: duas perspectivas sobre os estudos africanos," in Santos, B. S.; Meneses, M. P. (eds.) Epistemologias do Sul. Coimbra: Almedina.

Kane, Cheikh Hamidou (1963). Ambiguous Adventure. New York: Walker and Co.

Laban, Michel (1998). Moçambique - Encontro com Escritores. Porto: Fundação Eng. António Almeida, 3 Volumes.

Mbembe, Achille (2002). "African Modes of Self-writing," Public Culture, 14 (1): 239273.

Meneses, Maria Paula (2007a). “Os Espaços Criados pelas Palavras - Racismos, Etnicidades e o Encontro Colonial," in N. Gomes (ed.) Formação de Professores e a Questão Racial: uma visão além das fronteiras. Belo Horizonte: Autêntica Editora.

Meneses, Maria Paula (2007b). "Pluralism, Law and Citizenship in Mozambique: mapping the complexity," Oficina do CES, 291.

Meneses, Maria Paula (2010a). “O 'indígena' africano e o colono 'europeu': a construção da diferença por processos legais," E-cadernos CES, 68-93, available at http://www.ces.uc.pt/e-cadernos/ media/ecadernos7/04\%20\%20Paula\%20Meneses $\% 2023$ 06.pdf.

Meneses, Maria Paula (2010b). Legal Pluralism and Plural Memories: a view from Mozambique. Paper presented to the 2010 Conference of the Law and Society Association, Chicago, May 2010.

Meneses, Maria Paula; Ribeiro, Margarida Calafate. (2008). "Cartografias Literárias Incertas," in M. C. Ribeiro; M. P. Meneses (eds.). Moçambique: das palavras escritas. Porto: Afrontamento.

Meneses, Maria Paula; Santos, Boaventura de Sousa (2008). The Rise of a Micro Dual State: the case of Angoche (Mozambique). Paper presented at the CODESRIA Yaounde Conference, December 2008.

Mudimbe, Valentin Y. (1994). The Idea of Africa. Bloomington: Indiana University Press.

Ncomo, Barnabé Lucas (2003). Uria Simango: um Homem, uma Causa. Maputo: Edições Novafrica. 
Ruscio, Alain (2005). 1931: L'Apogée de la Bonne Conscience Morale. Paris: La Dispute editions.

Sheppard, Todd (2006). The Invention of Decolonization: the Algerian War and the ramaking of France. Cornell: Cornell University Press.

Santos, Boaventura de Sousa (2001). "Entre Próspero e Caliban: Colonialismo, Póscolonialismo e Inter-identidade," in M. I. Ramalho; A. Sousa Ribeiro (eds.). Entre Ser e Estar: Raízes, Percursos e Discursos de Identidade. Porto: Edições Afrontamento.

Santos, Boaventura de Sousa (2007). "Beyond Abyssal Thinking: from Global Lines to Ecology of Knowledges," Review Fernand Braudel Center, XXX (1): 45-89.

Smouts, Marie-Claude (ed.) (2007). La Situation Postcoloniale. Paris: Sciences PO.

Souto, Amélia Neves (2007). Caetano e o Ocaso do 'Império': Administração e Guerra Colonial em Moçambique durante o Marcelismo (1968-1974). Porto: Afrontamento.

Thiong'o, Ngugi wa (2009). Something Thorn and New: an African Renaissance. New York: Basic Civitas Books.

Human ARChitecture: Journal of THE Sociology of Self-KNOWLedge, X, ISsue 1, Winter 2012 